\title{
Effects of Reflective Inquiry Teaching Method on Students' Academic Achievement in Domestic Installation Module in Technical Colleges of Yobe State, Nigeria
}

\author{
Abubakar Baba Yerima ${ }^{1}$ \\ ${ }^{1}$ Nigerian Building and Road Research Institute, North East Zonal Office Gombe, Gombe State, \\ Nigeria
}

\begin{tabular}{|c|c|}
\hline Artic & Abstract \\
\hline & Purpose: The study investigated the effects of reflective inquiry teaching \\
\hline & method on students' academic achievement in domestic installation modules \\
\hline $\operatorname{Re}$ & in technical colleges of Yobe State, Nigeria. \\
\hline & $\begin{array}{l}\text { Methodology/Approach/Design: The study is quasi-experimental in design. } \\
\text { A pre-test and post-test were conducted for both control and experimental }\end{array}$ \\
\hline Keywords: & groups. Two classes from four Technical Colleges were selected to give a \\
\hline Reflective Inquiry, & sample size of 88. Electrical Installation and Maintenance Work Trade \\
\hline & ement Test (EIMWTAT) was used to generate data for the study. The \\
\hline & ent was validated by three experts in the Department of Electrical \\
\hline & $\begin{array}{l}\text { gy Education, Modibbo Adama University of Technology, Yola. To } \\
\text { e the reliability of the instrument. Cronbach's Alpha was used and }\end{array}$ \\
\hline $\begin{array}{l}\text { Installation, } \\
\text { 1 College }\end{array}$ & $\begin{array}{l}\text { determine the reliability of the instrument, Cronbach's Alpha was used and } \\
\text { a reliability coefficient of } 0.91 \text { was obtained. Mean statistics was used to } \\
\text { answer the research questions, while the null hypotheses were tested using t- }\end{array}$ \\
\hline Paper Type : & test at 0.5 level of significance. \\
\hline Research Article & $\begin{array}{l}\text { Results: The study revealed that reflective inquiry teaching method } \\
\text { improves student academic achievement when compared with the } \\
\text { demonstration teaching method. It further revealed that reflective inquirv }\end{array}$ \\
\hline $\begin{array}{l}\text { Corresponding Author: } \\
\text { Abubakar Baba Yerima }\end{array}$ & $\begin{array}{l}\text { teaching method is not gender biased as both male and female students } \\
\text { performed effectively in domestic installation. The study concluded that } \\
\text { when students are taught domestic installation using reflective enquiry } \\
\text { method, they performed better than when taught using conventional method. }\end{array}$ \\
\hline $\begin{array}{l}\text { Email: } \\
\text { babayerimafika@gmail.com }\end{array}$ & $\begin{array}{l}\text { Practical Implications: The results of the study may have implications for } \\
\text { teaching staff in Technical Colleges of Yobe State, Nigeria. Based on the } \\
\text { results of the study, the reflective method can be applied in the teaching and } \\
\text { learning of domestic installation, industrial installation and electrical } \\
\text { installation and maintenance works in technical colleges. } \\
\text { Originality/Value: The study innovates by experimenting with the effect of } \\
\text { reflective inquiry in teaching Domestic Installation Module in Technical } \\
\text { Colleges of Yobe State, Nigeria. From the analysis, the reflective inquiry } \\
\text { was found effective in teaching domestic installation as students' academic } \\
\text { achievement was significantly high. By this, the use of reflective inquiry in } \\
\text { the teaching of domestic installation, which is now being introduced, is } \\
\text { highly commendable. }\end{array}$ \\
\hline
\end{tabular}

\section{Introduction}

The term education has to do with the process of teaching or training an individual or individuals with all that is needed in the society. This training includes knowledge, skills, 
attitudes and values which are needed of a learner to withstand challenges in his environment (Tikka et al., 2000). Teaching involves the setting up of activities to enable someone learn something which can improve the person's knowledge, skills, attitude and value. Thus, the aim of teaching is to facilitate learning. Shodeinde (2013) defined teaching as the attempt to assist students in acquiring or changing some skills, knowledge, idea, attitude or appreciation.

Central to the process of teaching is the concept of effective teaching. In vocational and technical education, teaching methods and strategies are aimed at developing in the learners the ability to acquire knowledge and skills useful for work. These methods and strategies can vary in depth and time depending on the level of students and the materials available for instruction. According to Nwachukwu (2006), the task of organizing for effective teaching is crucial in any educational setting.

Reflective inquiry teaching method is, therefore, one of the envisaged techniques that, if effectively employed in the teaching of Electrical Installation and Maintenance Works Trade (EIMW), is likely to yield positive results in students' academic achievement. In the reflective inquiry teaching method, the teacher assumes the role of a facilitator of the teaching-learning process. The teacher provides the necessary direction to enable the learners decode and or re-arrange the knowledge towards discovering or finding solutions to problems or the answers to questions (Imogie, 1998). In reflective inquiry, students are guided to identify problems, think critically, reflect on previous knowledge, and collect information and other evidences that will help them solve problems, formulate hypotheses for solutions of the problems, test the hypotheses and apply the solution. Onyekwere (2001) had stated that the degree of understanding by students depends on several interacting variables. Onyekwere further observed that, students' readiness to learn while the teacher is teaching can be super fluxed by other variables such as lack of learning materials, lack of interest, school environment, teaching techniques and other factors.

For teaching to facilitate learning, Akindolu (2001) emphasized that the content to be taught has to be worthwhile and the procedure has to be educationally acceptable and has activities that can aid students' understanding. Therefore, Onyekwere (2001) stressed that teachers should endeavor to adopt teaching methods that are capable of reducing divergences on the part of students and yield positive results in students' academic achievement of both sexes.

According to Pandey (2008), academic achievement is the performance of the students in the subjects they study in school. It is directly related to students' growth and development of knowledge in an educational situation where teaching and learning takes place. Usman (2000) reiterated that academic achievement is the measure of students' learning acquisition of certain skills at the end of teaching and learning activities. As observed by Devis and Mayuri (2013), academic achievement is excellence in all academic disciplines, in classes as well as in extracurricular activities. However, Ali (2014), pointed out that students will be able to achieve better if the required instructional techniques and materials are appropriately and effectively utilized. 
Gender is another factor in technical education and achievement. Bichi (2002) defined gender as the amount of masculinity and femininity found in a person and obviously while there are mixtures of both in most human beings. Normally male has a preponderance of masculinity and the normal female has a preponderance of femininity. The concept "gender" has attracted the attention of many psychologists and researchers as a result of which a lot of literature exist on different aspect of education. The influence of gender on students' academic achievement has for a long time been a concern to many educational researchers. But surprisingly no consistent results have been obtained (Francis \& Babatunde, 2008). Philips (2006) argued that girls excel consistently in arithmetic computation and supervision in reading and hand writing, while boys are slightly better in arithmetic reasoning, geography, geometry and history. Usman (2000) observed that if male and female are exposed to activity-teaching strategy such as discovery outdoor and indoor strategies, they will perform equally well.

Electrical Installation and Maintenance Works (EIMW) Programme is one of the Technical and Vocational Education (TVE) programmes offered in technical colleges in Nigeria with domestic electrical installation as one of the modules. According to National Board for Technical Education (NBTE, 2004), the goals of domestic electrical installation module is to provide the trainee with the knowledge and skill to enable him carry out complete electrical installation in a building and its associated equipment, practice required understanding of electrical working diagrams, practice different types of domestic surface wiring and domestic conduit wiring, applying principles of protecting electrical devices and install them, carrying out sequence for inspecting and testing domestic installations and installing various types of lamps for illumination and other uses etc.

In the world of technology today, learners do understand concepts faster and easily recall them when they are actively engaged in the learning process. Olayinka and Oyenuga (2010) revealed that our classrooms are heavily dominated by the use of traditional teaching methods such as lecture, demonstration, project, etc. These methods emphasizes procedure of instruction in which majority of learners are merely passive listeners, while teacher plays the role of dispenser of knowledge. Aina (2000) observed that some of the factors responsible for the high failure rate of technical college students in the National Business and Technical Board (NABTEB) examinations particularly in the main trades include poor quality of teaching staff and the use of poor teaching methods. Ogwo (2004) remarked that the conventional teaching methods which are teacher-centered are the main teaching methods employed by technical teachers for implementing the curriculum. Hence, the question still remains: can reflective inquiry instructional technique produce significant effect on the academic achievement of students in domestic electrical installation modules in technical colleges?

\section{Literature Review}

Reflective inquiry is a process whereby individuals examine their experiences to better understand the assumptions and implications of events and actions in their lives through a close examination of information or truth. Inquiry and critical thinking have been universally 
accepted as being the ideals and central aim of education. It refers to the activity engaged in to overcome a situation of doubt to generate knowledge with provisional and tenuous results posited in the light of new experience and insight (Garrison, 2003). For reflective inquiry to have some practical value in a school environment with its multidisciplinary nature and developmental levels, reflective inquiry should be viewed as an overreaching concept and methods.

A classroom based on inquiry is more than a gathering of individual learners brought together for reasons of economy. Rather it is a community of inquiry. Onyekwere (2001) noted that reflective inquiry helps us consider our past understandings in the light of what we are learning, illuminating possibilities and helping us to choose which path to venture down next. Ultimately, the central meaning of scientific reflective inquiry revolves around two big ideas, reflective inquiry as the essence of scientific enterprise and reflective inquiry as a strategy for teaching and learning sciences and science related subjects The modern view on critical thinking has its genesis in the work of John Dewey and the method of scientific inquiry.

Critical thinking is seen as the means to personal meaning, (re)construction of knowledge and an educated person. To think critically is to make sense of things through questioning, debate and confirming understanding collaboratively. To Dewey, reflective activity occurs when a person decides to face perplexed, troubled or confused situation and prior to a clear-up unified and resolved situation. Five phases or aspects of reflective thought are presented. The first, according to Owodunni (2011), consists of suggestions. In this phase the mind leaps forward to a possible solution. The idea of what to do when finds in a fix is a substitute for direct action. It is a vicarious, anticipation way of acting a kind of dramatic rehearsal. The second phase is the intellectualization of the difficulty or perplexity that has been felt (directly experience) into a problem to be solved, a question for which the answer must be sought. This is affected by noting more definitely than the conditions that constitute the trouble and cause the stoppage of action. The third phase is the use of one suggestion after another as leading idea to create an insight into these suggestions and correctly modify and expand the suggestion that originally occurred, making the suggestion a definite supposition or hypothesis. This hypothesis is then used to initiate and guide observation and other operations in the collection of factual materials. The fourth phase is the mental elaboration of the idea or supposition (reasoning, in the sense in which is a part not the whole of inference).The fifth phase is testing the hypothesis by overt or imaginative action to give experimental corroboration or verification of the conjectural idea (Ali, 2014).

Empirical studies on effect of teaching methods on academic achievement by which science and technology education is taught to students have in recent times come under scrutiny. Studies have revealed that the teaching methods used in imparting knowledge on students have a great effect on their academic achievement. Several studies have been carried out on reflective inquiry and other strategies that encourage students' active involvement and that are capable of improving their thinking and problem solving skills. Ogbuanya and Owodunni (2013) carried out an investigation on the effect of reflective inquiry instructional technique on students' achievement and interest in Radio Television and Electronics Works trade 
(RTVE) in technical colleges in Lagos State of Nigeria. The design was purely quasiexperimental. Specifically the pre-test - post-test non-equivalent research design was used. The sample for the study consisted of all the 105 (76 boys and 29 girls) year two technical RTVE students. Four research questions were raised and answered using mean and standard deviation while six hypotheses guided the study and were tested at 0.05 level of significance using analysis of covariance (ANCOVA). The instruments used for data collection were RTVE Achievement Test (RTVEAT) and RTVE interest inventory (RTVEII). The findings of the study revealed that reflective inquiry instructional technique was more effective in improving students' achievement and interest in RTVE than conventional lecture method. The results also showed that gender, as an intervening variable, had significant influence on students' achievement and interest in RTVE in favour of boys. However, since Ogbuanya and Owodunni carried out their investigation to determine the effect of reflective inquiry instructional technique on students' achievement and interest in radio television and electronics works in technical colleges and not in electrical installation and maintenance works trade, this present study determined the possible effect of reflective inquiry instructional technique on students' achievement in electrical installation related contents of technical colleges.

Sadeh and Zion (2009) carried out a research on the development of dynamic inquiry performances within an open inquiry setting and guided inquiry setting on high school biology students in Ramat Gan, Israel. This study compared the influence of open versus guided inquiry learning approaches on dynamic inquiry performances among high-school biology students. They hypothesized that open inquiry students who engage in the inquiry process from its initial stage, participating in the decision making process of asking inquiry questions and planning all aspects of the inquiry, will outperform students who experienced guided inquiry, in terms of developing dynamic inquiry performances. Students were divided into two groups: guided and open inquiry learning approaches. Both groups were followed throughout their 2-year inquiry learning process. The data sources included interviews, students' inquiry summary papers, logbooks, and reflections. A quantitative content analysis of the two groups, using a dynamic inquiry performances index, revealed that open inquiry students used significantly higher levels of performances in the criteria changes during inquiry and procedural understanding. However, the study's results indicated no significant differences in the criteria learning as a process and affective points of view. This study is relevant to the present study in methodology but differ in geographical location as the previous study was conducted Israel while the present study will be conducted in Yobe State, Nigeria.

Sola and Ojo (2007) carried out a research study on the effect of project, inquiry and lecturedemonstration teaching methods on senior secondary student's achievement in separation of mixtures practical test in Osun State. The study assessed and compared the relative effectiveness of three methods for teaching and conducting experiments in separation of mixtures in chemistry. A pre-test, post-test experimental design with a control group was used. Two hundred and thirty three (233) randomly selected senior secondary school (SSS 1) chemistry students were drawn from four Local Government Areas of Osun State, Nigeria. 
The research instruments developed were a twenty five (25) items supply/select response questions used for the pre-test and post-test tagged Chemistry Achievement Test (CAT). Students were divided into three experimental and one control groups. Students in the three experimental groups were subjected to treatment using project, inquiry and lecturedemonstration method respectively, while students in the control group were taught using the traditional method of teaching. The pre-test was administered to students in all the four groups before teaching commenced and after the teaching and the experiment, a post-test was then administered. The study revealed that the results of ANOVA of the difference in the scores of the post-test of the project, inquiry, lecture-demonstration methods and control group showed a significant difference between the groups. Students taught with project method performed better in the Chemistry Achievement Test (CAT) than the students taught with lecture demonstration method, while those students taught with lecture-demonstration method performed better than those taught with inquiry method. Students taught with project method performed better than students taught with inquiry method. The study concluded that the project method enhanced better performance in chemistry practical better than either inquiry or lecture-demonstration method. Since this method enhanced better performance of students in chemistry practical, a similar method like reflective inquiry could also improve the performance of students in Electrical Installation and Maintenance Work.

Moses (2020) conducted a study on the effects of reflective inquiry teaching method on students' retention ability in domestic installation module in technical colleges of Yobe State, Nigeria. In guiding the study, two research questions and two hypotheses were formulated in line with the specific objectives. A pre-test - post-test non-equivalent control group quasi experimental research design was adopted for the study. Four intact classes from 4 technical colleges were selected to give a sample size of 88. Domestic Installation Retention Test (DIRT) was used to generate data for the study. To determine the reliability of the instrument, Cronbach's Alpha reliability method was used and a reliability coefficient of 0.84 was obtained. Mean statistic was used to answer the two research questions of the study while the two null hypotheses of the study were tested using t-test and ANCOVA at 0.05 level of significance. Findings of the study revealed among others that reflective inquiry teaching method enhances retention abilities in students when used in teaching domestic installation. It further revealed that male and female students' retention in domestic installation was high when taught using reflective inquiry teaching method. The study concluded that using reflective inquiry teaching method to teach students of electrical installation and maintenance works trade in Yobe State enhances the students' retention ability which is visible in the retention test scores. The study recommended among others that teachers should employ reflective inquiry teaching method while engaging students in more work that will enable them develop critical thinking abilities.

Robert (2006) compared the achievement of pre-service teacher education students enrolled in inquiry-based earth science courses and those enrolled in traditionally -based earth science courses in knowledge, comprehension and application proficiencies. The students were tested at the beginning of the semester (pre-test) and again at the end of the semester (post-test). A sample of students participated in post-test interview sessions designed to examine in depth 
their knowledge, comprehension and application proficiencies with regard to atmospheric science content. Classroom observation data related to the behavior of both students and instructions were collected and later coded and analyzed using a letter observation instrument. The findings revealed that students in the traditional course demonstrated gains in knowledge and comprehension that resulted in statistically significant improvements on the overall post-test scores. Students in the inquiry based courses accomplished some improvements in knowledge comprehension and application competencies that did not result in statistically significant improvements on the overall post test scores. Analysis of data suggested that the traditional course was more effective in preparing pre-service teachers to teach content consistent with the Michigan curriculum framework. The interpretation of the classroom observations and the interview sessions revealed that the inquiry-based courses were not fully consistent with national and state standards, included activities that did not adequately use investigative procedures and lacked several major content areas outlived by the Michigan curriculum framework which the pretest/post-test was based.

Egbita and Hassan (2019) carried out a study to determine the effects of reflective inquiry instructional technique on junior secondary school students' academic achievement in basic science and technology for sustainable national development. The study sample consisted of two classes of different secondary schools, one experimental with 88 students and the other one as control had 164 students. A random sampling technique using balloting method was used in selecting the two schools out of 31 public secondary schools in Minna metropolis, with a total population of 57,402 students in the metropolis. A pretest-posttest quasiexperimental research design was used. The instrument used was Basic Science and Technology Achievement Test (BSTAT) which was validated and with reliability coefficient of $\mathrm{r}=0.75$. The hypotheses stated were tested using t-test statistics at $\mathrm{P} \leq 0.05$ level of significance. Major findings of the study revealed that there is significant difference in the academic achievement among secondary school students exposed to reflective inquiry instructional technique and those exposed to conventional teaching method in favor of experimental group. There is also significant difference in the academic achievement of male students exposed to reflective inquiry instructional technique and female students exposed to the same treatment in favor of the male students. In light of the findings from this study, recommendations were offered. Government concerned with the responsibilities of managing the affairs of secondary schools should design special training programmes for basic science and technology teachers so as to keep them abreast with the current development in methodology of teaching and new innovations that are being invented by educational researchers offered among others.

\section{Methodology and Procedures}

The study adopted pre-test, post-test non-equivalent control group quasi-experimental research design. Owodunni (2011) stated that quasi-experimental research design investigates the possible cause and effect as well as relationship between two or more variables by the application of treatment which cannot be resolved by mere observation or description. The study was conducted in Yobe State of Nigeria. The population of this study comprised of all 
338 students of electrical installation and maintenance work trade of the eight technical colleges in Yobe State. The distribution of the technical colleges was based on gender (no mix technical school exists in the State). Purposive sampling technique was used to select four technical colleges in Yobe State for the study. The total sample size was 88 students in their Year II. The instrument that was used for data collection was tagged; "Electrical Installation and Maintenance Work Trade Achievement Test" (EIMWTAT). The EIMWTAT consisted of questions adapted from NABTEB past questions in electrical installation and maintenance work trade from 2012 - 2018 based on NTC II syllabus. The achievement test consisted of 50 multiple-choice items with four (4) options lettered A-D, which were given, scores. Data collected for this study were analyzed as follows: mean statistic was used to answer the two research questions, while the null hypotheses were tested using t-test at 0.05 level of significance. To answer the research questions of the study, both pre-test and posttest mean scores of experimental and control groups were compared for mean difference. Higher mean score showed better achievements. The decision for testing the two null hypotheses of the study was that; when the calculated t-value was lower than the p-value, the null hypothesis was accepted, conversely, the null hypothesis was rejected.

\section{Results and Discussion}

Research Question 1: What is the mean achievement score of electrical installation and maintenance work students when taught domestic installation using reflective inquiry teaching method and demonstration teaching method in technical colleges in Yobe State?

Table 1: Mean and Standard Deviation of Academic Achievement Score of Electrical Installation and Maintenance Work Students Taught Domestic Installation Using Reflective Inquiry Demonstration Teaching Methods

\begin{tabular}{lcccc}
\hline & \multicolumn{2}{c}{ Control $\mathbf{n}=\mathbf{8 8}$} & \multicolumn{2}{c}{ Experimental $\mathbf{n}=\mathbf{8 8}$} \\
& (Demonstration Teaching Method) & \multicolumn{2}{c}{ (Reflective Inquiry Teaching Methods) } \\
\multicolumn{1}{c}{ Group } & $\overline{\boldsymbol{x}}$ & $\boldsymbol{\sigma}$ & $\overline{\boldsymbol{x}}$ & $\boldsymbol{\sigma}$ \\
\hline Pre-test & 29.75 & 11.83 & 30.34 & 11.52 \\
Post-test & 51.71 & 9.70 & 66.48 & 16.45 \\
Mean gain & +21.96 & & +36.14 & \\
\hline
\end{tabular}

Key: $\mathrm{n}=$ Number of Students, $\bar{x}=$ Means Scores, $\sigma=$ Standard Deviation

Source: Authors

The result in Table 1 showed that the control group had a pre-test mean score of 29.75 and a standard deviation of 11.83. Furthermore, the control group post-test mean achievement score improved with a mean score of 51.71 and a standard deviation of 9.70. The students in the experimental group had a mean achievement score of 30.34 and a standard deviation of 11.52 in the pre-test, while after the treatment, the experimental group (Reflective Inquiry teaching method), scored 66.48 and a standard deviation of 16.45. Comparatively, the mean score of the experimental group is higher than that of the control group that was thought using the demonstration method. 
This finding revealed that reflective inquiry teaching method improves student academic achievement when compared with the demonstration teaching method. This finding is in agreement with Ogbuanya and Owodunni (2013) who reported that reflective inquiry instructional technique was more effective in improving students' achievement and interest in Radio, Television and Electronics (RTVE) Works than conventional lecture method. This finding is also in synergy with findings of Sadeh and Zion (2009) who stated that reflective inquiry method of instruction improve students' academic performance in Basic electricity.

Research Question 2: What are the mean achievement scores of male and female students of electrical installation and maintenance work students when taught domestic installation using reflective inquiry teaching methods in technical colleges in Yobe State?

Table 2: Mean and Standard Deviation of Academic Achievement Scores of Male and Female Students Taught Domestic Installation Using Reflective Inquiry Instructional Techniques Conventional Teaching Method

\begin{tabular}{lcccc}
\hline \multicolumn{1}{c}{ Scores } & Male $\mathbf{n}=\mathbf{5 2}$ & \multicolumn{3}{c}{ Female $\mathbf{n}=\mathbf{3 6}$} \\
& $\overline{\boldsymbol{x}}$ & $\boldsymbol{\sigma}$ & $\overline{\boldsymbol{x}}$ & $\boldsymbol{\sigma}$ \\
\hline Pre-Test & 29.48 & 9.33 & 21.55 & 9.18 \\
Post-Test & 63.80 & 13.54 & 61.77 & 12.60 \\
Mean difference & +34.32 & & +40.22 & \\
\hline
\end{tabular}

Key: N= Number of Students, $\bar{x}=$ Means Scores, $\sigma=$ Standard Deviation, Mean Diff. $=$ Mean Difference Source: Authors

The result presented in Table 2 showed that the male students had a mean score of 29.48 in the pre-test and 63.80 in the post-test. This makes the pre-test - post-test mean difference of +34.32. The female students had a mean score of 21.55 in the pre-test and a post-test mean of 61.77 with a pre-test -post-test mean difference of +40.22 . With this result, the male and female students performed better in the achievement. Hence, reflective inquiry instructional technique is effective for teaching both gender as it is not gender bias when used for teaching domestic installation.

The finding of the study on research question 2 revealed that reflective inquiry teaching method is not gender biased as both male and female students performed effectively in domestic installation. This finding is in line with Sola and Ojo (2007)who reported that reflective inquiry method enhanced better performance in chemistry practical better than either project or lecture method. Furthermore, in line with the finding of this study, Mbah (2002) asserted that reflective inquiry method was superior to expository method. However, Mbah further stated that regardless of method of instruction, students who are internally controlled performed better than students who are externally controlled.

Hypothesis 1: There is no significant difference between the mean achievement score of electrical installation and maintenance work students when taught domestic installation using reflective inquiry teaching method and demonstration teaching method in technical colleges in Yobe State. 
Table 3: t-test Analysis of Post-test Mean Achievement Scores of Students Taught Domestic Installation Using Reflective Inquiry and Demonstration Teaching Methods

\begin{tabular}{lccccccc}
\hline Teaching Methods & $\mathbf{N}$ & $\bar{x}$ & $\sigma$ & df & t & p & Remark \\
\hline Reflective Inquiry(Experimental) & 43 & 64.58 & 14.49 & & & & \\
& & & & 86 & 5.132 & 0.000 & Sig. \\
Demonstration Method (Control) & 45 & 54.26 & 11.70 & & & & \\
\hline
\end{tabular}

Key: $\mathrm{N}=$ Number of Students, $\bar{x}=$ Means Scores, $\sigma=$ Standard Deviation, $\mathrm{Df}=$ Degree of Freedom, Sig. $=$ Significant Source: Authors

T-test analysis in Table 3 was carried out to measure whether significant difference in the achievement scores of students exists between those taught using reflective inquiry teaching method and those taught using demonstration teaching method. The results showed that there was significant difference in the mean achievement scores between students taught domestic installation using reflective inquiry teaching method and those taught using demonstration teaching method, $\left[\mathrm{t}_{86,0.05}=5.132, \mathrm{p}<0.05\right]$ in favour of those taught using the reflective enquiry teaching method [64.58 > 54.26]. It was therefore conclude that the experimental group taught using the reflective enquiry teaching method performed better.

The finding of hypothesis one revealed that there was significant difference between academic achievement of students taught domestic installation using reflective inquiry instructional method and those taught using demonstration teaching method in technical colleges in Yobe state. This finding is in line with Ogbuanya and Owodunni (2013) findings who reported that there was significant difference in the mean achievement scores of students taught radio television and electronics works trade using reflective inquiry instructional technique and conventional lecture method. This finding is also in agreement with findings of Sadeh and Zion (2009) who reported that significant difference existed between students taught basic electricity using reflective inquiry instructional technique and conventional lecture method.

Hypothesis 2: There is no significant difference between the mean achievement scores of male and female students of electrical installation and maintenance work students when taught domestic installation using reflective inquiry teaching methods in technical colleges in Yobe State.

Table 4: t- test Analysis of Male and Female Students Mean Achievement Scores

Taught Domestic Installation Using Reflective Inquiry Teaching Methods

\begin{tabular}{cccccccc}
\hline Gender & $\mathbf{N}$ & $\bar{x}$ & $\Sigma$ & df & t & P-Value & Remark \\
\hline Male & 52 & 63.80 & 13.54 & & & & \\
Female & 36 & 61.77 & 12.60 & & & & \\
& & & & & & & \\
\end{tabular}

$\mathrm{N}=$ Number of Students, $\bar{x}=$ Means Scores, $\sigma=$ Standard Deviation, $\mathrm{df}=$ Degree of Freedom, Sig. $=$ Significant

Source: Authors

T-test analysis was carried out to test whether significant difference in the mean achievement scores of male and female students exist when taught using reflective inquiry teaching method. The results in Table 4 shows that there was no significant difference in the mean 
achievement scores of male and female students taught domestic installation using reflective inquiry teaching method [t $86,0.05=0.808, \mathrm{p}<0.05]$. The null hypothesis was therefore accepted since the $p$-value $(p=0.201)$ was greater than the significant level of 0.05 .

The finding on hypothesis 2 revealed that there is no significant difference between the mean achievement scores of male and female students of electrical installation and maintenance work students when taught domestic installation using reflective inquiry teaching methods in technical colleges in Yobe State. This finding is in agreement with Ali (2014) who conducted a study in Kano State, Nigeria on the ability of male students using inquiry-based learning method and found out that there was no significant difference between the mean achievement scores of male student in the experimental and control groups.

\section{Conclusion and Suggestion}

The study concluded that when students are taught domestic installation using reflective inquiry teaching method, the academic achievement of students improves than when taught using demonstration method of teaching. It is also concluded that reflective inquiry teaching method is more effective than the demonstration teaching method in enhancing students' achievement in domestic installation.

Based on the findings and of the study, it is suggested that the State ministry of education should encourage the use of reflective inquiry method of instruction in the technical colleges in Yobe State. Since reflective inquiry method of instruction is more effective in improving students' academic achievement, school administrators should ensure that teachers within the schools adopt the teaching method.

\section{Acknowledgements}

The author wish to acknowledge the contributions of Dr. D. Moses for giving him the guidance and space to learn and grow, and for his patience, enthusiasm, and most of all for readiness to attend to the study from inception till now. Special thanks also to Prof. L. C. Ezugu and Dr. E. F. Mele for reading this work at both content and design stages respectively and to Mr. Isaac John Ibanga for helping in the draft of this manuscript. Finally the support of my immediate family and staff of Nigerian Building and Road Research Institute, Gombe Zonal Office Nigeria is hereby acknowledged.

\section{Conflict of Interest}

The authors of the article declare no conflict of interest.

\section{Funding}

The costs of conducting the study and for publishing this article are of the authors.

\section{Availability of Data and Material}

The data that support the findings of this study are available from the corresponding author, upon reasonable request. 


\section{References}

Aina, O. (2000). Nigeria technical and vocational education in the near future. In Federal Ministry of Education (2001), The National Master-plan for Technical and Vocational Development in Nigeria in the 21st Century with the Blue Print for the Decade 2010. Abuja, FME.

Akindolu, R. (2001). Dictionary of guidance and counselling psychology. Ibadan: Olu-Akin Publishers

Ali, A. (2014). The Effect of Inquiry-based Learning Method on Students' Academic Achievement in Science Course. Universal Journal of Educational Research2 (1), 37 41. http://www.hrpub.org DOI: 10.13189/ujer.2014.020104

Bichi, S. S. (2002). The effect of gender on academic performance in evolution concepts among secondary school students using problem-solving instructional strategy, Zaria. Journal of Studies in Education, 3(1), 133 - 138.

Devis, S., \&Mayuri, K. (2013). The effects of family and school on the academic achievement of residential School Children. Journal of Community Guide Resources, 20(2), 139-148

Egbita, U. A. \& Hassan, A. M. (2019).Effect of reflective inquiry instructional technique on junior secondary school students' achievement in basic science and technology for sustainable national development. Academic Staff Union of Research Institutions, 11(1), 11-17

Francis, A.\& Babatunde, G. (2008).Investigating Gender Difficulties and Misconception in Inorganic Chemistry at Senior Secondary School Level. International Journal of African-America Studies, 7(11), 1 - 7.

Garrison J. (2003). Inquiry and Critical and Critical thinking-Reflective Inquiry. Learning Commons Communities of Inquiry. New York: Garis Publishers

Imogie, A. I. (1998). Improving Teaching and Learning: An Introduction to Instructional Technology. Benin-city: Joesseg Associates

Mbah.F. I (2002).Learning and teaching methodology. Journal of Education and Social Research,2 (4), 16 - 20

Moses, D. (2020). Effects of reflective inquiry teaching method on students' retention ability in domestic installation module in technical colleges of Yobe State, Nigeria. International Journal of Science and Research (IJSR), 9(9), 919-923

National Board for Technical Education (2004).Curriculum for Technical Colleges. Kaduna: NBTE.

Nwachukwu, C.E. (2006). Designing appropriate methodology in vocational and technical education for Nigeria. Nsukka: University Trust Publishers.

Ogbuanya T. C. \& Owodunni A. S. (2013).Effects of Reflective Inquiry Instructional Technique on Students' Academic Achievement and Ability Level in Electronic Work Trade in Technical Colleges.3(1), 133 - 138

Ogwo, A. (2004). Functionality Vocational Education in Nigeria Public schools. Some policy paradigms. Enugu: Magnet Business Enterprise.

Olayinka, O. and Oyenuga, A.O. (2010). Integration of Automobile Technological College Motor Vehicle Mechanics Works Curriculum, RSS, 8(2) 
Onyekwere, P. E. (2001): Child Development; Theory and Practice. Lagos: T-Excel publishers.

Owodunni, A.S. (2011). The effect of reflective inquiry instructional technique on academic achievement and interest on radio, television and electronics work students in technical colleges. [Published Doctoral Dissertation], University of Nigeria, Nsukka.

Pandey, R. G. (2008). Academic achievement as related to motivation and parental background. Indian Psychological Revolution, 70(4), 213-216.

Robert, J. (2006). Analyzing the Effects of Inquiry-Based Instruction on the Learning of Atmospheric Science among Pre-Service Teacher Education Students. [Unpublished Doctoral Dissertation], Western Michigan University.

Sadeh, I. \& Zion, M. (2009). The development of dynamic inquiry performances within an open inquiry setting: A comparison to guided inquiry setting. Journal of Research in Science Teaching: The Official Journal of National Association of Research in Science Teaching, 46(10)1137-1160.

Shodeinde, A. O. (2013).Effect of Cognitive Mind Mapping on the Achievement of Electrical and Electronic Trades Students. [Unpublished Master's Thesis] Department of Vocational Teacher Education, University of Nigeria, Nsukka.

Sola, A. O., \&Ojo, O. E. (2007). Effects of project, inquiry and lecture-demonstration teaching methods on senior secondary students achievement in separation of mixtures practical test. Educational Research and Reviews, 2(6), 124-132.

Tikka, P.M., Kuitunen, M.T., \&Tynys, S.M. (2000).Effects of educational background on students' attitudes, activity levels and knowledge concerning the environment. The Journal of Environmental Education, 31(3), 12-19.

Usman, I.A. (2000).The Relationship Between Students Performance in Practical Activities and their Academic Performance in Integrated Science, Using NISTEP Mode of Teaching. [Unpublished Doctoral Dissertation], Faculty of Education, Ahmadu Bello University. 